\title{
BIOAEROSOLS AND HEALTH: CURRENT KNOWLEDGE AND GAPS IN THE FIELD OF WASTE MANAGEMENT
}

\section{Olivier Schlosser *}

SUEZ, CIRSEE, 38 rue du Président Wilson, 78230 Le Pecq, France

Article Info:
Received:
8 October 2018
Revised:
11 February 2019
Accepted:
4 March 2019
Available online:
31 March 2019
Keywords:
Bioaerosols
Endotoxin
Fungi
Exposure
Health
Organic waste

\section{INTRODUCTION}

As an alternative to landfill disposal, processes are being developed that ensure recycling and energy recovery of biodegradable fractions of waste. In the European Union, the bio-fraction of municipal solid waste (MSW) and commercial and industrial waste (C\&IW) has been estimated at 189 and 133 wet million tons, respectively, in 2014 (Arup URS Consortium, 2014).

Biodegradable fractions of waste include: (1) biowaste segregated by households and commercial and industrial activities and (2) the organic matter/waste fraction that remains in dry recovered waste and in residual waste when dry solid waste is segregated by households for separate collection. (Park et al., 2011a ; Schlosser et al., 2015 ; Tolvanen et al., 2001, 2004). Further processes aim at separating the organic wet fraction from the dry solid recovery waste, and to treat it mainly by composting, anaerobic digestion, or stabilisation. Consequently, the biodegradable fraction of waste is present in all MSW and C\&IW management sectors.

The development of biodegradable waste recycling leads to increased amounts of decaying organic materials handled. The age of the waste, environmental conditions such as humidity and temperature, and some processes, such as composting, encourage the growth of micro-organisms in the biodegradable waste fraction and associated products. These factors encourage the conditions in which workers, households and neighbouring communities are potentially exposed to airborne biological agents, i.e., bioaerosols (Pankhurst et al., 2011a; Pearson et al., 2015; Schlosser et al., 2015; Wouters et al., 2000).

Bioaerosols consist of live and dead micro-organisms either as individual micro-organisms or as aggregates, fragments and micro-organisms products, such as bacterial endotoxins, $\beta$ (1-3)-D glucans and mycotoxins. All these biological agents can also be carried by other particles (ACGIH, 1999). The interest of scientists and health authorities in bioaerosols has increased over the past two decades due to the wide range of adverse health outcomes associated with exposure in occupational and residential environments. These include infections, immuno-allergic, non-allergic inflammatory and toxic effects (ACGIH, 1999; ADEME, 2012; Douwes et al., 2003; Dutkiewicz, 1997; Swan et al., 2003).

The main objective of this study was to assess the knowledge and gaps relative to bioaerosol-related health issues in the field of MSW and C\&IW management activities, and to have an insight into the weight of evidence from the literature and SUEZ experience. Additional objective 
was to identify priority issues for research in order to improve knowledge and prevention. As a preamble, is briefly given background information on bioaerosols and related health issues.

\section{MATERIALS AND METHODS}

A scoping review of the literature covering the topic of bioaerosols in the waste management field between 1990 and 2018 was carried out. The literature search for peer-reviewed scientific publications has been conducted on Medline, accessed via PubMed. In addition, technical and grey literature publications were searched using internet-wide search engines (Google, Google Scholar).

Studies were included in this review if they reported data in the MSW/C\&IW management field on at least one of the following topics: biohazard identification, bioaerosol measurement, exposure assessment, health outcome in exposed people (case reports, epidemiological studies), quantitative microbial risk assessment, experimentation in humans, measures of prevention, regulation. Studies on bioaerosols from wastewater treatment plants and healthcare waste management activities were not included in the review. In addition to studies specific to the MSW and C\&IW management field, articles about the measurement methods and the health effects of bioaerosols were included in the scoping review.

Overall, 368 studies were selected. Of these, 165 were related to bioaerosol monitoring in the field of MSW and C\&IW, and 48 to epidemiology. Overall, $77 \%$ of the articles were related to the field of occupational exposure. For each of the waste management sectors, the identified studies were critically assessed in order to estimate whether or not hazard identification, exposure assessment and health effect (epidemiological studies, case reports) aspects were "sufficiently", "insufficiently" or "not" documented. An aspect was qualified as "sufficiently documented" if there were numerous studies that present similar conclusions, "insufficiently documented" if major gaps in knowledge still persisted regarding one or more issues, "not documented" if no documentation reporting the data mentioned above was found. It is noteworthy that industrial composting was by far the most investigated sector, accounting for $53 \%$ of the studies included. Inversely, in regards to food waste depackaging technology, as far as it could be established, only internal data was available.

\section{BACKGROUND INFORMATION ON BIOAE- ROSOLS AND RELATED HEALTH EFFECTS}

Bioaerosols are ubiquitous in nature, however some human activities such as animal farming, gain harvesting and handling, wood processing, the food industry, the textile industry, and waste management may substantially influence them both quantitatively and qualitatively $(\mathrm{ACGIH}$, 1999; Douwes et al., 2003; Eduard et al., 2012; Oppliger and Duquenne, 2015; Rylander and Jacobs, 1994). Bioaerosols are airborne particles, and thus, strictly speaking, gaseous metabolites such as microbial volatile organic compounds (mVOC) are not considered as bioaerosols (ACGIH, 1999;
Vilavert et al., 2012). Airborne biological agents can be free in air, such as mould spores, or carried by another particle, of organic or mineral content. Individual bioaerosols range in size from $<0.01 \mu \mathrm{m}$ to $100 \mu \mathrm{m}$ in diameter (ACGIH, 1999).

Biological agents in aerosol can be transmitted through three routes:

The inhalation route, which exposes the mucous membrane of the airways and the lungs to the agent impact according to the aerodynamic diameter $\left(D_{a e}\right)$ of the particulate. The smaller the inhaled particle, the deeper the deposit into the lung. In addition, largest inhaled particles that impacted in upper airways ( $D_{\text {ae }}$ above $10 \mu \mathrm{m}$ ) can be swallowed in a second phase;

- the ingestion route, mainly by the contact of dirty hands to the mouth or through a direct projection of materials on face, and also from inhaled coarse particles as mentioned above;

- and the skin and eye contact mode.

\subsection{Health outcomes of bioaerosols}

Adverse health effects of inhaled bioaerosol can be divided into infectious diseases and non-infectious effects.

\subsubsection{Infectious diseases}

Bioaerosol inhalation is recognised as one of the main transmission routes for infectious diseases (Eames et al., 2009; Moretti et al., 2018; Qian and Zheng, 2018; Valade et al., 2015; Yates et al., 2016). Infection requires that a micro-organism (bacteria, viruses, fungi) be alive, and the severity of the disease depends on the virulence of the strain and individual risk factors, such as immune deficiency. Depending on the micro-organism, the reservoirs are humans, animals and/or the environment. The occurrence of airborne infectious diseases is facilitated by the clustering of people in close environments (e.g., influenza, tuberculosis) and by exposures that are specific to occupations (e.g., Q-fever in farmers, psittacosis in bird breeders) or environments (e.g., legionellosis, non-tuberculous mycobacterial pulmonary disease, histoplasmosis) (Cavalazzi et al., 2018; Clark et al., 2018; Drummond et al., 2019; Herwaldt et al., 2018; Hogerwerf et al., 2017; Maloney et al., 1995; McKinsey et al., 2011). Health care workers, veterinarians, farmers and biomedical workers have been identified as carrying out high risk occupations (Douwes et al., 2003).

Some micro-organisms are opportunistic pathogens; this means that infection occurs when the host defenses are compromised by disease or the treatment of the disease. Immune deficiency is the most common condition associated with opportunistic infection, including malignant disease, organ transplantation and human immunodeficiency virus (HIV) infection (Bunch and Crook, 1998). Opportunistic airborne micro-organisms include fungi (moulds, such as Aspergillus fumigatus, Zygomycetes species, Fusarium, Coccidiodes immitis, and yeasts such as Cryptococcus neoformans and Pneumocystis jirovecii) and bacteria (e.g., Mycobacterium Avium Complex, Pseudomonas aeruginosa, Micrococcus) (Brandt and Warnock, 2007; Clifton and Peckham, 2010; Lande et al., 2018; Lemonovich, 2018; Lin, 2009; Ma et al., 2018). 


\subsubsection{Non-infectious effects}

Non-infectious effects of inhaled bioaerosols gather inflammation of airways from non-allergic mechanisms (usually cytokine-mediated effects), immuno-allergic respiratory diseases (asthma, rhinitis, hypersensitivity pneumonitis) that need previous sensitization to the allergenic compound(s) of the micro-organism, and toxic effects on organs (liver, kidney, central neurologic system, immune system, ...) (ACGIH, 1999; Douwes et al., 2003; Rylander and Jacobs, 1994). Main non-infectious effects due to inhaled bioaerosols are summarized in Table 1. Non-infectious effects do not need the micro-organism to be alive; dead micro-organisms and fragments do keep pro-inflammatory and allergenic properties. Some mycotoxins (Aflatoxin B1) are classified as carcinogenic to humans (Group 1) by the International Agency for Research on Cancer (IARC, 2012). The critical route of exposure to mycotoxins is usually ingestion, however, there is growing evidence that lung can also be a target for aflatoxin B1 carcinogenicity (Donnelly et al., 1996; Jakšić et al., 2012; Marchese et al;, 2018; Massey et al., 2000).

Occurrence of immuno-allergic outcomes is influenced by both features of exposure to micro-organisms (the level and duration of exposure, occurrence of peaks of exposure), and the presence of individual risk factors, such as atopy for asthma, or asthma and cystic fibrosis for allergic bronchopulmonary aspergillosis (ABPA), which is the principal clinical disorder due to Aspergillus hypersensitivity (Denning et al., 2013; Knutsen and Slavin, 2011). In addition, sensitisation to $A$. fumigatus has also been associated with reduced lung function in severe asthma and chronic obstructive pulmonary disease patients (Denning et al., 2014; Fairs et al., 2010). The burden of allergic fungal airway disease is important. In a scoping review, Denning et al. (2013) estimated that the prevalence of ABPA in adults with asthma was $2.5 \%$, whilst modelling suggests an ABPA global burden of 4.8 million adult patients. As regards severe asthma with fungal sensitisation, the global burden has been estimated at about 6.5 million patients (Denning et al., 2014). Furthermore, thermophilic actinomycetes and fungi are well-known causal agents of occupational hypersensitivity pneumonitis (ACGIH, 1999; Eduard, 2009; Quirce et al., 2016).

At the workplace, exposure to endotoxins has been associated with both acute and chronic respiratory outcomes, due to their pro-inflammatory properties (Rylander,
2006). Short-term respiratory and systemic outcomes can lead to sick leaves, and repeated exposure to high levels of endotoxins have been associated with chronic bronchopulmonary disorders and reduction in lung function (Searl et al., 2008). Endotoxin exposure substantially aggravates airways inflammation in patients with allergic rhinitis and atopic asthma (Michel et al., 1989; Rylander, 2006). Moreover, it has been shown that genetic variations in proteins that mediate endotoxin recognition impact the airways and immune response to endotoxin exposure (Holla et al., 2002). These data emphasize that the response to endotoxin exposure is not similar between individuals.

The results of workplace studies suggest that the development of respiratory symptoms as a result of exposure to bioaerosols is likely to lead to chronic respiratory illness following prolonged exposure (Rylander, 2006) and this negative effect is biologically plausible due to chronic inflammatory reaction of the respiratory tract (Bolund et al., 2017; Liebers et al., 2008). A recent meta-analysis of the association between organic dust (i.e., bioaerosol) exposure and decline in lung function, the first of its kind, showed a small significant excess loss in forced expiratory volume in the first second (FEV1) (on average $4.92 \mathrm{~mL}$ / year) among exposed compared with controls (Bolund et al., 2017). However, the authors highlight that this small excess decline could lead to possible important health issues after many years of exposure. Furthermore, the healthy worker selection bias (i.e., the potential bias caused by the phenomenon that more susceptible individuals may be excluded from employment or, once employed, may leave the job they do not tolerate) could be an evident problem in all the studies included in this review and may suggest that the associations found were underestimated (Bolund et al., 2017). Other symptoms associated with bioaerosol exposure are nausea, diarrhoea, headache and fatigue (Douwes et al., 2001; Gladding and Cloggins, 1997; Hambach et al., 2012; Ivens et al., 1999; Krajewski et al., 2004).

On the other hand, it is worth noting that microbial exposure, and particularly exposure to endotoxins may have a protective effect against atopy and asthma, as suggested by epidemiological studies in farmers (Eduard et al., 2004; Riedler et al, 2001) and recent experimental works (Schuijs et al., 2015). Several epidemiological studies also support hypothesis that endotoxin exposure may protect against lung cancer, as a result of stimulation of cytokin release, and notably Tumor Necrosis Factor a (TNFa) (Ben

TABLE 1: Non-infectious effects from exposure to airborne micro-organisms.

\begin{tabular}{|c|c|c|c|c|}
\hline Microorganisms & Constituents/Metabolites & Allergy & Non-allergic inflammation & Others $^{b}$ \\
\hline Gram negative bacteria & Endotoxin & & + & \\
\hline $\begin{array}{l}\text { Non-sporulated Gram } \\
\text { positive bacteria }\end{array}$ & Peptidoglycans & & + & \\
\hline Fungi & $\begin{array}{l}\text { Allergens } \\
\beta(1-3) \text {-D-glucans } \\
\text { Mycotoxins }\end{array}$ & $\begin{array}{l}+ \\
\mathrm{a}\end{array}$ & $\begin{array}{l}+ \\
+\end{array}$ & c \\
\hline Thermophilic actinomycetes & $\begin{array}{l}\text { Allergens } \\
\text { Peptidoglycans }\end{array}$ & + & + & \\
\hline
\end{tabular}

a: Enhancement of the allergic response to inhaled allergens; b: Others: cytotoxic and carcinogenic effects; $c$ : Limited evidence of systemic and carcinogenic effects of inhaled mycotoxins, in contrast with ingested mycotoxins. 
Khedher et al, 2017; Lenters et al., 2010). However, optimal dose of exposure to endotoxin, if any, is unknown, as on the other hand long-term exposure to endotoxin is associated with chronic bronchopulmonary disorders as mentioned above.

\subsection{Main gaps in knowledge on bioaerosol health effects}

Several gaps remain in our knowledge of the potential health impact of exposure to bioaerosols generally, and notably from MSW and C\&IW regardless of the specificity of the activity or process. These gaps concern each of the four steps of health risk assessment process (USEPA, 2018): hazard identification, exposure assessment, exposure-response relationship and health risk assessment.

\subsubsection{Hazard identification}

Exposure to bioaerosols is often estimated by analysis of microbial sum parameters in air samples using culture-based methods, and less frequently by microscope examination (ACGIH, 1999; Cartwright et al., 2009; Douwes et al., 2003; Eduard, 2009; Eduard et al., 2012). As highlighted above, bioaerosol in the organic waste management field is a complex mixture of microorganisms, constituents and metabolites. Moreover, bioaerosol exposure is associated with a large variety of symptoms and diseases. In fact, it is often not clear which agents are primarily involved in health outcomes that have been described by exposed groups. Many biological agents that may cause health effects are currently not identified. Even if a few studies carried out a large identification approach for microorganisms with molecular biology (quantitative PCR) (Le Goff et al., 2010; Pankhurst L.J. et al., 2012) or mass spectrometry (MALDI-TOF) (Madsen et al., 2016; Nasir et al., 2018a), or investigated specific antigens with enzyme immunoassays (van Kampen et al. 2014), data in most studies do not reflect the variety of different species. New biomolecular technologies such as next-generation DNA sequencing can help in informing on the microbial diversity and the relative abundance of airborne microorganisms and in identifying indicators for monitoring bioaerosols emission (Duquenne et al., 2018). Such indicators may help to distinguish the contribution of a specific source, such as a non-hazardous waste landfill, versus other sources (such as intensive poultry farming). They have been applied to the waste management field for a very few years (Degois et al., 2017; Dubuis et al., 2017; Mbareche et al., 2017, 2018; Wéry et al., 2018). In fact, there is a need for identification of indicator parameter(s) for exposure assessment and health risk assessment in the specific field of interest, depending on the goal of the study (Douwes et al., 2003). There is a need for clear demonstration of the relevance of the selected indicator parameter, according to the question to be answered. For example, to answer the question of assessing bioaerosol dispersion in the surroundings of composting facilities, a combination of three microbial indicators using culture-independent techniques (viable bacteria using solid-phase cytometry, and two bacterial phylotypes, affiliated to Saccharopolyspora sp and the Thermoactinomycetaceae, respectively, using $\mathrm{qPCR}$ ) has been proposed as a rel- evant marker for monitoring composting aerosol (Le Goff et al., 2012). However, this combination would be would be of little interest for assessing the health effects of exposure of neighbouring residents to composting bioaerosols. To answer part of that question, the focus will rather be on micro-organisms such as Aspergillus fumigatus, which is a real concern for the health of susceptible individuals (Deacon et al., 2009a; Epstein, 1994; Kramer et al., 1989; Schlosser et al., 2016).

\subsubsection{Exposure assessment}

Exposure assessment is closely linked to the sampling strategy, which includes the selection of the collection and analysis methods and the sampling plan (stationary and personal sampling, sampling locations, sampling duration and sample size) (ACGIH, 1999; ADEME, 2012; Douwes et al., 2003; Eduard and Heederik, 1998). Measurement of bioaerosols should be performed according to a protocol representative of the exposure pattern and duration at the workplace or in the surrounding environment. Different factors may influence the pattern of exposure to bioaerosol components and the variability in exposure levels. The study design and the sampling strategy should take these factors into consideration. Furthermore, the particle size dispersion should be taken into account, for both health risk assessment process and bioaerosol dispersion modelling (Byeon et al., 2008; Galès et al., 2015; Rolph and Gladding, 2017).

As a major key point, there is a lack of valid methods to assess exposure, and of protocols that should include internationally accepted guidelines on sampling, transport and storage, and analytical procedures (Duquenne et al., 2013; Searl et al., 2008; Walser et al., 2015). This lack makes it difficult to compare the results of the different exposure studies, and of epidemiological findings. Several documents have been published by standardisation organisations or occupational health and safety institutes that describe protocols of bioaerosol measurement at the workplace. However, these protocols are not internationally recognised, and some of these documents should be reviewed to incorporate newly available knowledge (Duquenne et al., 2013). In Europe, the European Committee for Standardization (Comité Européen de Normalisation, CEN) published three standards in the early 2000s, EN 13098 (CEN, 2000), EN 14031 (CEN, 2003) and EN 14583 (CEN, 2004). EN 13098 and EN 14031 are currently being revised by the CEN technical committee 137.

Alongside the identification of appropriate indicator parameters, there is a need for developing standardized measurement methods and for harmonized approach to sampling strategy. There is also a clear need for developing continuous monitoring methods which provide real-time information (Nasir et al., 2018b; O'Connor et al., 2015; Robinson et al., 2013).

\subsubsection{Exposure-response relationship}

Regarding bioaerosols, exposure-response relationship is lacking for most agents (ACGIH, 1999, Eduard, 2009, Searl et al., 2008; Walser et al., 2015). Indeed, establishing exposure-response relationships for bioaerosols is difficult due to: (1) the definition of exposure (e.g., what indicator 
parameter? what exposure time scale? what exposure unit?), (2) the definition of the response (what critical effect as the relevant endpoint? threshold versus non-threshold response?), and (3) the complexity of the mixture of micro-organisms and components in bioaerosols. Moreover, the combined effects of biological agents (such as endotoxin and specific allergens) should not be ruled out. Neither should interactive effects between bioaerosols and chemical hazards such as ammonia and volatile organic compounds (Viegas et al., 2017). These points highlight potential differences in response to an environmental indicator depending on the occupational sector (e.g., differences in response to endotoxin exposure in pig farming versus paper and cardboard recycling depending on other associated air pollutants).

Establishing exposure-response relationships also faces difficulty associated with variation between individuals and within individual (i.e., over-time) in the response to a particular inhaled biological agent. There is a need for investigating the issue of individual susceptibility to allergens, endotoxin and other bioaerosol components, and the potential influence on the shape of the exposure-response relationships.

There is a need for further research on exposure-response relationships for most bioaerosol components.

\subsubsection{Health risk assessment}

According to the above sub-sections, it is obvious that health risk characterization regarding bioaerosols, and in the waste industry particularly, is seriously hampered by several major gaps in each of the constitutive steps of the process. That means we cannot precisely predict the risk of a particular health outcome associated with a specific job, nor can we for general community. Owing to the lack of established exposure-response relationship for inhaled biological agents, quantitative microbial risk assessment (QMRA) cannot be performed.

As an alternative to a predictive approach with risk characterization, epidemiological studies provide observational results and risk measurement estimate. However, regarding bioaerosols, available epidemiological studies do not provide strong evidence that would allow establishment of exposure-response relationships and subsequent exposure limits (Walser et al., 2015). There is a need for further epidemiological studies, particularly prospective cohort studies, which allow consideration of both exposure level and individual risk factors as covariates. If ethically feasible, experimental studies involving human subjects may also help to establish health-based guidelines for airborne biological agents, such as endotoxin (Health Council of the Netherlands, 2010).

Whatever the risk assessment approach, large uncertainties in exposure assessment (mainly due to the lack of reliable and standardized quantitative exposure assessment methods) greatly hamper the development of legal health-based exposure limits for most bioaerosols (Douwes et al., 2003). A few specific components are exceptions, such as subtilisin, which is an enzyme produced by Bacillus subtilis and used in detergents, and endotoxin, as mentioned above (Douwes et al., 2003; Eduard et al.,
2012). In the Netherlands, $90 \mathrm{EU} \mathrm{m}^{-3}$ has been proposed as a health-based recommended limit (8-hr time-weighted average) for endotoxins at the workplace, which affords adequate protection against the effects of both acute and chronic exposure (Health Council of the Netherlands, 2010). Otherwise, regulatory occupational exposure limits have been set for cotton, grain, wood, and flour dust, however these limits do not consider specific components present in the dust (Eduard et al., 2012).

\section{BIOAEROSOLS FROM MSW AND C\&IW MA- NAGEMENT AND HEALTH: WHAT WE KNOW AND WHAT WE DO NOT KNOW}

This section synthetizes knowledge and gaps related to bioaerosols in the MSW and C\&IW management field. Some data are specific to this sector, other ones are more generic as they apply to other occupational and environmental fields.

\subsection{What are the target groups regarding exposure to bioaerosols from MSW and C\&IW management activities?}

Main target groups are workers, households and nearby residents of waste management facilities. Additional target groups are represented by occasional visitors of the facility (school pupils, municipal representatives, ...) and since recently by pupils and teachers in schools where an on-site composting program has been implemented (Brown, 2005; Garden Organic, 2018; Green Mountain Farm to School, 2010). There are marked differences in features of target groups and in respective exposure patterns that can influence the response of individuals to bioaerosols. Workers in MSW and C\&IW management activities are clearly the target group with highest levels of exposure. Workers are adults, generally healthy (although some of them may present asthma and/or be smokers), and high levels of exposure to bioaerosols from waste are limited to the working time. Households may be exposed to MSW bioaerosols from separate storage of biowaste and home composting. Households' exposure is intermittent, but may occur over the lifetime. Individuals may obviously be ill and present risk factors. Residents living or working nearby open air waste management facilities (composting plants, non-hazardous waste landfill sites) may be exposed to bioaerosol emissions from the facility. Residents' exposure is irregular, depending on the on-site activity, and may potentially occur all over the lifetime. These individuals may also be ill and present risk factors.

As a result, although exposed to highest concentrations of bioaerosols, waste workers should not be considered as a "sentinel group" for surveillance programs on health impact of bioaerosols. In other words, the absence of reported health problems among workers does not mean there is no risk among household members, neighbouring residents and school pupils. Waste workers are not representative of the general population, as they may be markedly different with regard to individual risk factors and exposure patterns. 


\subsection{What do we know about waste workers' exposu- re to bioaerosols?}

MSW and C\&IW materials present in the waste management sectors contain micro-organisms from biodegradable fraction of incoming waste, and from the growth of bacteria and fungi favoured by humidity and temperature (Miller and Clesceri, 2002; Pahren, 1987; Palmisano and Barlaz, 1996). Microorganism occurring in bioaerosol from MSW and C\&IW are mainly fungi and bacteria, and are divided into four major groups: Gram-negative bacteria, Gram positive bacteria, actinomycetes and fungi (Dutkiewicz, 1997) (Table 2). The composition of bioaerosols depends on the nature of the feedstock and the processed used. For example, in the composting process, mesophilic bacteria and fungi in feedstock are succeeded by thermophilic actinomycetes and fungi species as the temperature rises above $45^{\circ} \mathrm{C}$ (Millner et al., 1994; Swan et al., 2003). Exposure to viruses in solid waste processing facilities is poorly documented. Human adenovirus and Torque teno virus (which has been proposed as an indicator of viral faecal contamination in the environment) have been detected in the air of waste disposal and recycling plants (Carducci et al., 2013). Most of human adenovirus positive air samples were able to grow in cell culture and were thus considered infective. In another study, human adenovirus genome could not be quantified in any of the air samples from biomethanization facilities (Traversi et al., 2018).

Levels of exposure to bioaerosols in the MSW/C\&IW industry are highly variable between sectors and within individual sectors, and between workers and within workers (variation in personal exposure over time) (Spaan et al., 2008; Wouters et al., 2006) (Figure 1). Measurement uncer- tainty might be factor of variation; however, waste composition, extended residual waste collection cycles, enclosed vs. open air facility, types of process, season, tasks being performed and control measures in place are major potential determinant factors of bioaerosol concentration in the air (Gladding et al., 2003; Gladding and Gwyther, 2017; Persoons et al., 2010, Schlosser et al., 2009, 2015; Sykes et al., 2011; Wouters et al., 2006). Processes that are particularly associated with high levels of exposure to bioaerosols are all sources of mechanical agitation (waste unloading, stored waste handling, shredding, screening, windrow turning, material transfer operations, truck loading) or tasks involving manual agitation of waste (manual sorting of waste, cleaning and maintenance operations, blockage clearing) (Millner et al., 1994; Persoons et al., 2010; Sanchez-Monedero et al., 2005; Schlosser et al., 2009, 2015; Taha et al., 2006). In addition, vehicle traffic on dirty roadways contributes to bioaerosol emission (Epstein et al., 2001; Millner et al., 1994; Reinthaler et al. 2004). All these processes and activities generate dust, which contains biological agents. In a recent multivariable study, the level of inhalable dust has been shown to be the factor that most influenced within-site variability in endotoxin and culturable bacteria concentration in the air in sewage sludge composting facilities (Schlosser et al., 2018). These findings suggest that measurement of dust can efficiently assist decision making for prevention measures against endotoxin and bacteria in sludge composting plants. Further work could help to determine whether inhalable dust may be used as a marker of exposure to endotoxin and other airborne biological agents in other fields of waste management.

The highest levels of exposure to airborne bacteria and

\section{Concentration in air - Maximum (CFU m $\mathrm{m}^{-3}$ or $\mathrm{EU} \mathrm{m}^{-3}$ )}

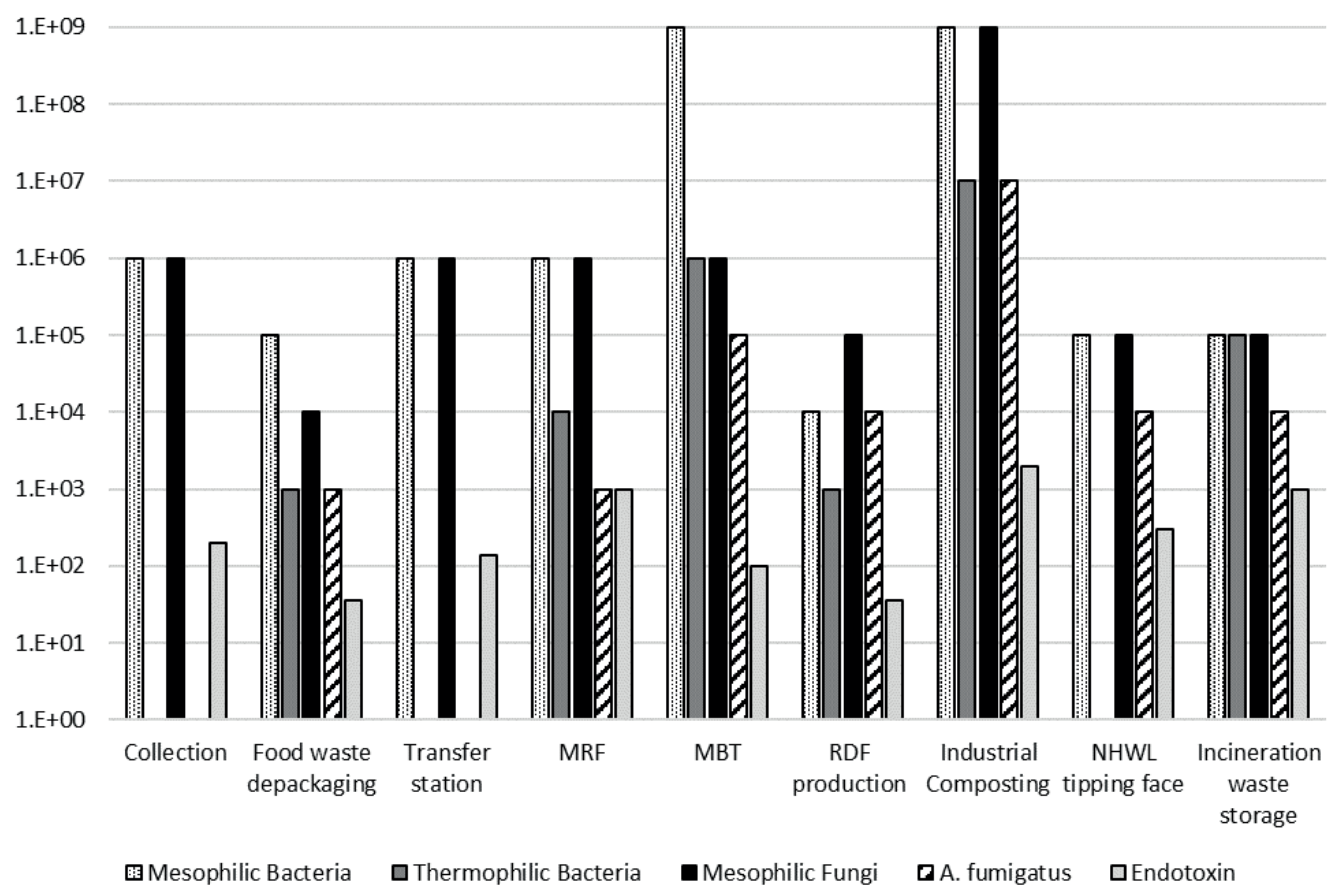

FIGURE 1: Maximum concentrations (orders of magnitude) of bioaerosols in waste management activities reported in the literature and from internal measurements. 
fungi have been reported at composting sites and mechanical biological treatment (MBT) facilities (Pearson et al., 2015; Persoons et al., 2010; Schlosser et al., 2009; Searl, 2008; Sykes et al., 2011; Tolvanen and Hänninen, 2005; Wouters et al., 2006), followed by material recovery facilities (MRFs) and during waste collection operation (Cerna et al., 2017; Gladding and Coggins, 1997; Lavoie et al., 2002; Madsen et al., 2016; Neumann et al., 2002; Nielsen et al., 1995; Schlosser et al., 2015; Würtz and Breum, 1997) (Figure 1). These exposure levels were 100 to 100,000 times higher than highest outdoor background levels. Levels of exposure to endotoxins reached several tenths or hundreds Endotoxin Units $\mathrm{m}^{-3}$ in most sectors. These exposure levels were 10 to 1000 times higher than outdoor background levels.

\subsection{What do we know about bioaerosol-related risk for waste workers' health?}

In the MSW and C\&IW field, associated microorganisms are mostly not pathogens, i.e. they are not infectious for healthy people. However, a few are real pathogens, such as Legionella species (Conza et al., 2013; Currie et al., 2014) or enteric pathogens in pet excrements and disposable diapers (Gerba et al., 1995, 2011). Some airborne microorganisms (mainly fungi, such as Aspergillus fumigatus and Zygomycetes species) may act as opportunists in fragile people, that are immunocompromised or present lung damages often associated with prescription of steroids (Cornillet et al., 2006; Latgé, 1999; Roden et al., 2005). These individual risk factors are significant determinants of the risk of severe fungal infection. However, it is worth stressing that huge levels of exposure to $A$. fumigatus spores have been associated with severe Aspergillus infection in immunocompetent persons (Arendrup et al., 2006; Jung et al., 2014; Russell et al., 2008; Zuk et al., 1989). These atypical cases are rare.

Case reports of respiratory disease in waste workers, with either immune-allergic, non-allergic inflammatory or infectious mechanism, provide evidence in support of an association with bioaerosol exposure in composting plants and in MRFs (reviewed by: ADEME, 2012; Schlosser et al.,
2009, 2015; Swan et al., 2003). However, case reporting does not mean a confirmed excess of risk, and epidemiological investigations are necessary to estimate whether the risk is significantly increased in exposed workers and how large this increase may be. In the field of MSW/ C\&IW management, most epidemiological studies are of cross-sectional design (29 out of the 48 studies identified). Most of these studies agree in indicating an excess of upper airway (nose and throat), eye and respiratory tract irritation symptoms in exposed workers (e.g., Athanasiou et al., 2010; Bünger et al., 2000; Gladding et al., 2003; 2010; Hambach et al., 2012; Heldal and Eduard, 2004; Heldal et al., 2015; Hoffmeyer et al., 2014; Ray et al., 2005; Schantora et al., 2015). These findings support the hypothesis of an inflammatory effect of bioaerosol exposure in waste workers, which is confirmed by the association between inflammatory symptoms of the airway and increases in inflammation cells and markers in nasal lavage or induced sputum samples (Douwes et al., 2000; Heldal et al., 2003; Wouters, 1999). Furthermore, several studies showed a cross-shift decline in respiratory function in waste workers exposed to bioaerosols (Heldal et al., 2003, 2015; Sigsgaard et al., 1994). However, quantitative evidence of an excess risk of chronic respiratory disease following longterm exposure to bioaerosols in the waste industry is limited. In a 5-year follow-up study in composting workers, a slight decline of the Forced Vital Capacity in percent of predicted (FVC\%) of the non-smoking compost workers was observed during the observation period compared to control subjects (Bünger et al., 2007). Conversely, in a prospective study over 5 years in garbage collectors in Switzerland, the respiratory function was not altered (Tschopp et al., 2011). The authors emphasize that the lack of effect of bioaerosols in this population probably resulted from low exposure levels due to good working conditions. In a 13year follow-up study in Germany, van Kampen et al. (2016) demonstrated that working as a compost worker for more than 5 years significantly increased the risk of coughing by an average of $28 \%$ and that for cough with phlegm by an average of $32 \%$, suggesting an increased risk of chronic bronchitis. However, compared to controls, no higher inci-

TABLE 2: Micro-organism genera or species most often isolated from bioaerosols in the MSW management field.

\begin{tabular}{|c|c|c|}
\hline Group of micro-organisms & Origin & Microorganism genera or species \\
\hline \multirow[t]{2}{*}{ Gram-negative bacteria } & Fresh and stored plant materials & Pantoea, Pseudomonas, Klebsiella, Aeromonas, Rahnella, Flavobacterium \\
\hline & Animal products & Acinetobacter \\
\hline Gram-positive bacteria & $\begin{array}{l}\text { Animal products and stored plant } \\
\text { materials }\end{array}$ & $\begin{array}{l}\text { Coryneform bacteria (Arthrobacter, Corynebacterium, Brevibacterium, Microbacte- } \\
\text { rium), cocci (Staphylococcus, Micrococcus, Streptococcus), spore forming bacilli } \\
\text { (Bacillus), Listeria }\end{array}$ \\
\hline \multirow[t]{2}{*}{ Actinomycetes } & Stored plant materials & $\begin{array}{l}\text { Thermophilic species (Saccharopolyspora rectivirgula, Thermoactinomycetes } \\
\text { vulgaris, Saccharomonospora viridis, Thermomonospora spp) }\end{array}$ \\
\hline & Soil and vegetable materials & Mesophilic species (Streptomyces, Rhodococcus, Agromyces) \\
\hline \multirow[t]{3}{*}{ Fungi } & $\begin{array}{l}\text { Saprophytic and pathogen plant } \\
\text { fungi }\end{array}$ & Cladosporium, Alternaria, Fusarium, Davidiella, Didymella, Curvularia, Drechslera \\
\hline & Decaying organic matter & $\begin{array}{l}\text { Penicillium, Aspergillus, Acremonium, Paecilomyces, Zygomycetes species (Rhizo- } \\
\text { pus, Mucor, Absidia) }\end{array}$ \\
\hline & Low-moisture food waste & Wallemia \\
\hline
\end{tabular}

Sources : ADEME, 2012; Cerná et al., 2017; Degois et al. 2017; Dutkiewicz, 1997; Huang et al., 2002; Kalwasinska et al., 2014 ; Krajewski et al., 2002 ; Lis et al., 2004 ; Madsen et al., Mbareche et al., 2018 ; 2016 ; Nielsen et al., 1997; Pinto et al., 2015 ; Rahkonen et al., 1990 ; Viegas et al., 2014 ; Wéry, 2014. 
dence of loss of respiratory function during the follow-up was observed in compost workers. A distinct improvement in health protection measures during the 13 years of study (which reduced the level of exposure to bioaerosols) and a potential healthy worker effect are limitations of the study. To date, no other long-term prospective epidemiological studies have been published.

It is important to stress that several factors may suggest that prevalence of respiratory disorders in the waste industry is under-reported. Some of these factors are associated with potential selection bias due to the healthy worker effect, the employment patterns in the waste industry, the low specificity of most symptoms, and the time scale over which chronic respiratory disease usually develops.

Nevertheless, as supported by exposure data in the waste industry and epidemiological findings in other sectors such as agriculture, farming, and textile industry, strong qualitative evidence links occupational exposure to bioaerosols in the waste industry to adverse effects on health including long-term respiratory disease, notably in the fields of composting, MBT and MRF (Pearson et al., 2015; Schlosser et al., 2009, 2015; Searl, 2008). In a richly documented report delivered to DEFRA in UK in 2008, strong warnings were issued about the potential for bioaerosols to cause major respiratory health problems to waste workers in the future (Searl, 2008; Letsrecycle.com news, 2009).

These data emphasize the need for appropriate preventive measures against bioaerosols at the workplace in the MSW and C\&IW industry, even if the epidemiological evidence is limited. As highlighted by the literature review, the levels of exposure to dust and bioaerosols vary within individual waste management sector, suggesting that there is potential to reduce exposures through good practice and prevention measures. These measures involve facility and process design, operational activities and, as a last resort, personal protection. The positive effect of vehicle technical factors has been demonstrated in the waste collection field (Breum et al., 1996; Neumann et al., 2002, 2005). At MRFs, several prevention measures have been recommended, such as adopting a site layout that uses separate areas for different processes, adopting a first in-first out order of treatment of the incoming waste, installing appropriate ventilation and dust capture systems in the processing areas, and installing adequate ventilation systems in the sorting rooms (Felten et al., 2001; INRS, 2011; Rapp et al., 2009; Schlosser et al., 2015; Stagg et al., 2013). Furthermore, in order to reduce microbial growth in the incoming waste, households are requested to dispose raw waste and biowaste into the container for separate collection and use containers with a cover in order to protect waste from the rain (INRS, 2011; Schlosser et al., 2015). In composting plants, several preventive measures have been recommended, such as dust control measures that include moisture control of the feedstock and composting, screening operation in a separate area from composting operations, sealing of the turning machinery with rubber mats, dust capture systems, adequate ventilation in buildings, regular cleaning and wetting of driveways, and protection of the vehicle cab with a pressurisation and high efficiency particulate air (HEPA) filtration system (Epstein, 1996, 2001;
Millner et al., 1994; Reinthaler et al., 2004, Schlosser et al., 2012; Spencer and Alix, 2006; Sykes et al., 2007). Furthermore, frequent windrow turning has been shown to reduce $A$. fumigatus on the compost surface due to improved thermohygienisation, resulting in a reduction in cumulative health risk despite more frequent turnings (Fischer et al., 1998). In all waste management sectors, the use of respiratory protective equipment (at least a FFP2/N95 filtering half mask) is recommended for tasks during which workers are most exposed, such as cleaning and maintenance. All these recommendations are based on common sense, however, quantitative data on their efficiency is limited (Breum et al., 1996; Epstein et al., 2001; Neumann et al., 2002, 2005; Park et al., 2011a; Rapp et al., 2009; Schlosser et al., 2012, 2015). Moreover, there is no consensus on the advantages (control of dust emission)-disadvantages (e.g., microbial growth due to humidity, dirty equipment) balance of the use of water spray misters in the waste management field and quantitative data is lacking (Epstein et al., 1996, INRS, 2011, Millner et al., 1994; Schlosser et al., 2015; Spencer and Alix, 2006; Stagg et al., 2013). Further research, and notably intervention studies, is needed in order to better assess the efficiency of prevention measures against bioaerosols at the workplace.

\subsection{What are the main gaps in knowledge about ex- posure to bioaerosols and related risks for waste workers' health?}

As a general rule, most studies investigated microbial sum parameters (e.g., mesophilic fungi), endotoxins, and mainly $A$. fumigatus as a micro-organism species. There is a lack in hazard identification in all sectors, as mentioned above, and exposure to some biological agents such as mycotoxins and Legionella is poorly documented. Workers' exposure to bioaerosols is not or insufficiently documented in several fields: this is the case for activities in household waste recycling centres (HWRC), waste transfer stations, MBT facilities, non-hazardous waste landfill sites(NHWL), incineration plants, and for those associated with refusederived fuel (RDF) production or food waste depackaging. Importantly, there are major knowledge gaps in all sectors about identification of determinant factors of bioaerosol exposure at the workplace and the size effect of these determinants. Most exposure studies are descriptive works, or only bivariable statistical analysis was performed. Another gap is the limited data on personal sampling, as compared to results of stationary sampling. These personal measurement results are necessary for estimating actual worker's exposure. Moreover, most personal samplings were full-shift and resulted in time-weighted averaged exposure estimates. Information on task-specific exposure is needed in most sectors for appropriate health risk management. Finally, most of epidemiological studies in the waste industry are cross-sectional designed, generally involving small numbers of subjects, and they provide limited information for exposure-response relationship. Prospective cohort studies are lacking, for both short-term health adverse effects and long-term ones (Bünger et al., 2007; Tschopp et al., 2011; van Kampen et al., 2016). 
4.5 What do we know about households' exposure to bioaerosols and associated health risk, and what are the major gaps?

Limited data suggests that separate storage of biowaste by households could increase exposure to bioaerosols and health effects in susceptible individuals (Herr et al., 2004; Naegele et al., 2016; Wouters et al. 2000). However, data on personal exposure associated with separate storage of biowaste by households is lacking. Potential impact that could be associated with changes in collection regime (switch for fortnightly collection of residual waste, extension of the sorting instruction of plastic packaging) would deserve attention; however, it is extremely poorly documented (Gladding and Gwyther, 2017; Schlosser et al., 2015). In particular, it should be stressed that home composting raises the question of potential health risk for susceptible individuals, mainly because of potential exposure to high concentrations of $A$. fumigatus. This hypothesis is supported by two severe infection case reports (Jung et al., 2014; Russel et al., 2008), and the occurrence of a deadly invasive pulmonary aspergillosis associated with gardening in the UK reported by Russel et al. (2008) has been given a lot of media coverage (National Health Service, 2008). However, households' personal exposure to $A$. fumigatus during compost agitation is not documented. To our knowledge, no epidemiological study is available.

In addition to home composting, urban community composting and composting programs at school are being developed. However, there is very little work on associated health issues (Pankhurst et al., 2011a), and to the best of our knowledge personal exposure is not documented. Strong evidence supports causality between exposure to moulds and the development and exacerbation of asthma in children (ANSES, 2016). Implementing an on-site composting program at school can expose vulnerable children to mould spores when turning and handling compost and further research is needed.

\subsection{What do we know about nearby residents' expo- sure to bioaerosols from MSW/C\&IW treatment faci- lities and associated health risk?}

Regarding bioaerosols, potential health impact on nearby residents is primarily relevant for open-air composting facilities (Pankhurst et al., 2011b; Taha et al., 2006) and NHWL sites (Reinthaler et al., 1999; Schlosser et al., 2016). This issue can also be addressed for on-site waste handling in the open as it generates bioaerosol emission, and for enclosed composting facilities and MRFs as biofilter exhaust contains bioaerosols (Ibanga et al., 2018; Sanchez-Monedero et al., 2003).

A. fumigatus and thermophilic actinomycetes species have been identified as relevant indicators for monitoring of bioaerosols in the surrounding areas of large-scale outdoor composting facilities (Albrecht et al., 2008; Environment Agency, 2018; Le Goff et al., 2012). Data on bioaerosol monitoring in the surrounding environment of open-air composting facilities shows that concentrations generally drop to near-background levels within $300 \mathrm{~m}$, although raised levels of exposure may occasionally arise at distance of up to
$500 \mathrm{~m}$ from composting facilities (Pankhusrt et al., 2011b; Recer et al., 2001). Data on bioaerosol measurements in the surroundings of NHWL sites is limited. A recent study suggested that mesophilic moulds and $A$. fumigatus may be transported beyond $500 \mathrm{~m}$ from the property boundary at concentrations above those found locally upwind of the landfill site (Schlosser et al., 2016). In addition to distance from the facility, other mitigation factors linked to the facility design have been the focus of published studies. These measures contribute to reduce the off-site transport of bioaerosols and include site enclosure, negative pressure of the air above the composting process, installation of biofilters, bioscrubbers equipped with a droplet separator, or equipment with a dielelectric barrier discharge reactor (Ibanga et al., 2018; Millner et al., 1994; Morey et al., 2003; Park et al., 2011b; Sanchez-Monedero et al., 2003; Schlegelmilch et al., 2005). Removal efficiency was different depending on the equipment and the micro-organism, however, it did not reach 2 log removal (i.e., 99\% reduction in concentration). Building berms and planting trees at appropriate locations on the site have been recommended as measures that can alter wind dispersion patterns and offsite transport of bioaerosols (Millner et al., 1994). The benefit of forest barriers on particulate dispersion has been demonstrated experimentally (Raynor et al., 1974) and highlighted regarding composting (Millner et al., 1994). Forest barrier both dilutes the particulate concentration in the plume and induces impaction and deposition of particles onto foliage.

Community-based epidemiological data is very limited. In a cross-sectional study in Germany, health questionnaires were collected from residents near a large-scale composting site and from unexposed controls (Herr et al, 2003). Residents exposed to bioaerosol pollution were shown to report irritative respiratory complaints independently of perceived odours. Recently, a national-scale study in England showed that it is unlikely that there is an increased risk of severe respiratory health outcome in healthy nearby residents of large-scale composting facilities (Douglas et al., 2016). However, such a conclusion cannot be drawn for minor respiratory health problems and for vulnerable groups.

\subsection{What are the main gaps in knowledge about bioaerosol exposure of nearby residents of MSW/ C\&IW treatment facilities and related health impact?}

There is a lack of information on dispersion of biological agents from waste facilities that may be of health concern for nearby residents. This is especially the case for opportunist Zygomycetes mould species and pathogenic species of Legionella from composting sites. Data on dispersion of endotoxin in the surrounding environment of waste processes is quite limited (Danneberg et al., 1997; Deacon et al., 2009b). Moreover, sampling strategies that have been performed (short sampling time that provides only a snapshot of concentrations at the time of sampling) do not provide information on long-term exposure, which is particularly important for community-based health studies (Pearson et al., 2015). Real-time bioaerosol sensors based 
on light-induced fluorescence techniques, such as SIBS (spectral intensity bioaerosol sensor), are being developed, however, SIBS equipment is still in its infancy and further research is needed (Nasir et al., 2018b). To the best of our knowledge, there is as yet no large-scale prospective study on adverse health effects on residents of bioaerosols emitted from composting facilities that has been conducted, and no data is available on the potential health impact of bioaerosols on nearby residents of NHWL sites and other plants with waste handling in the open. Importantly, there is no information on the potential impact of bioaerosols (and mainly $A$. fumigatus) from waste management plants on vulnerable groups such as immunocompromised, patients with lung damage and asthmatics.

Attempts have been made to use atmospheric dispersion models for predicting bioaerosol concentration in the surrounding environment of composting facilities. However, despite recent improvement, there is still limited confidence in these predictions due to uncertainties in source term definition and dispersal characteristics (Douglas et al., 2017).

The definition of a "safe" buffer distance from the site has been proposed as one of the responses to manage potential health risks for nearby residents of waste management sites. At that distance, bioaerosol concentrations should be reduced to the background levels. The principle is that if at this distance the outdoor background levels are not exceeded, there is no threat of excess health risk linked to the facility's presence (Schlosser, 2017). However, this statement raises two problems. First, outdoor background levels of bioaerosols need better characterization as they vary both temporally and spatially (Pearson et al., 2015; Schlosser et al., 2017). Secondly, the setting of a hypothetic "safety boundary" around waste management facilities is based on the non-rejection of null hypothesis in difference tests. That is to say, the setting of the safe buffer distance is linked to the power of the statistical test, and notably to the number of measurement results. A study designed with a large sampling plan may lead to conclude that at a given distance, bioaerosol concentrations are still significantly higher than background levels, even if this increase is low and does not suggest an unacceptable risk for health. On the other hand, the absence of a rejection of the null hypothesis could be linked to a lack of the power of the statistical test, especially because the sample size was too low. There is a need to explain what is meant by "bioaerosols concentration should be reduced to background levels" and to stress that the definition of a safety distance is based on a statistical approach (Schlosser et al., 2017).

\subsection{What do we know about visitors' exposure to bioaerosol and associated risk for health?}

To the best of our knowledge, this issue has not been addressed and neither published article nor grey literature is available.

\section{CONCLUSIONS AND PROSPECTS}

The synthesis of data from the literature on the health outcomes of bioaerosol exposure and exposure patterns in the MSW and C\&IW industry highlights the following key points:

- Levels of exposure to fungi, bacteria and endotoxins at the workplace can be very high if appropriate prevention measures are not taken. The highest levels of exposure are a real concern for the respiratory health of workers in the long term;

- The literature review does not provide evidence of an excess risk to the health of nearby residents of openair waste management facilities, such as composting plants or non-hazardous waste landfill sites. However, one of the key aspects when addressing this issue is the potential presence of at-risk individuals among nearby residents, such as patients with immune deficiency or severe lung damage. Fungal opportunistic pathogens, such as Aspergillus fumigatus or Zygomycetes species, are ubiquitous and not specific to organic waste decomposition and the waste management field. In the absence of exposure-response relationships, the relevant question is whether the level of exposure to airborne biological agents of interest is significantly increased by the presence of the facility, as compared to the outdoor background levels. Facility siting and design, operational changes and dispersion control measures can help to reduce bioaerosol emission and transport off-site;

- Waste handling may be of concern for the health of households if they have individual risk factors for adverse effects related to fungal exposure (e.g., immunodeficiency, asthma, severe lung damage, cystic fibrosis). This question is especially relevant for home composting. Urban community composting and composting at-school raises the same question.

However, this scoping review also highlighted numerous gaps in knowledge.

First, there are general needs for further research on the bioaerosol and health topic, regardless of the waste industry field. There are needs particularly for hazard identification and definition of relevant environmental indicators, for identification of health endpoints as the dependent variable in health studies, for standardized measurement methods, for better characterization of background bioaerosol levels, for investigation of impacts in vulnerable groups, and for more knowledge on interaction of bioaerosols with chemical pollutants and on potential protective effects of bioaerosols on atopic diseases and cancers.

Then, there are specific needs for further research in the field of the MSW/C\&IW industry. Several knowledge gaps should be filled as a priority: identification of relevant indicators for exposure and health studies, reliable and detailed assessment of personal exposure, estimate of factors influencing the level of exposure at the workplace, estimate of the benefit of the control measures that have been implemented on sites to reduce exposure to bioaerosols, well-designed epidemiological studies that would especially estimate the health risk over long time scales, validation of dispersion models predicting concentration in the surrounding environment of open-air 
sites and especially composting plants. Several sectors have been poorly investigated, such as HWRC, food waste depackaging technology, MBT, RDF production, NHWL and incineration.

Most importantly, valid and standardized methods for quantitative exposure assessment are needed to better assess health risk and contribute to establish reliable health-based guidelines for bioaerosols. However, available exposure and health data emphasize the need for appropriate preventive measures against bioaerosols in MSW and C\&IW handling and treatment activities, including workers training, medical examination prior to employment and regular surveillance. Furthermore, information should be given to susceptible individuals about potential biohazards associated with home composting and on-site composting at school.

\section{FUNDING}

Funding for this project was provided by SUEZ. The author declares no conflict of interest relating to the material presented in this article.

\section{REFERENCES}

ACGIH (1999). American Conference of Governmental Industrial Hygienists. Bioaerosols Assessment and Control; Macher J Ed, Cincinatti: ACGIH Press. ISBN: 882417-29-1.

ADEME (Agence de l'Environnement et de la Maitrise de l'Energie) (2012). The ADEME research programme on atmospheric emissions from composting. Research findings and literature review. Final report, July 2012.

http://www.ademe.fr/sites/default/files/assets/documents/85087_ emission_miseenligne_anglais2.pdf (accessed 31/08/2018)

Albrecht A., Fischer G., Brunnemann-Stubbe G., Jäckel U., Kämpfer P. (2008). Recommendations for study design and sampling strategies for airborne microorganisms, MVOC and odours in the surrounding of composting facilities. Int. J. Hyg. Environ. Health., 211, 121-31.

ANSES (2016). Moisissures dans le bâti. Agence nationale de sécurité sanitaire de l'alimentation, de l'environnement et du travail, Report, 345 p. In French. https://www.anses.fr/fr/system/files/ AIR2014SA0016Ra.pdf (accessed 31/08/2018)

Arendrup M.C., O'Driscoll B.R., Petersen E., Denning D.W. (2006). Acute pulmonary aspergillosis in immunocompetent subjects after exposure to bark chippings. Scand. J. Infect. Dis., 38, 945-9.

Arup URS consortium (2014). Advanced Biofuel Feedstocks - An Assessment of sustainability. Report for the Department for Transport, UK. Lead Supplier: E4tech Ltd (UK). https://assets.publishing.service.gov.uk/government/uploads/system/uploads/ attachment_data/file/277436/feedstock-sustainability.pdf (accessed 31/08/2018)

Athanasiou M., Makrynos G., Dounias G. (2010). Respiratory health of municipal solid waste workers. Occup. Med. (Lond.), 60, 618-23.

Ben Khedher S., Neri M., Guida F., Matrat M., Cenée S., Sanchez M., Menvielle G., Molinié F., Luce D., Stücker I.; ICARE Study Group (2017). Occupational exposure to endotoxins and lung cancer risk: results of the ICARE Study. Occup Environ Med., 74, 667-679.

Bolund A.C., Miller M.R., Sigsgaard T., Schlünssen V. (2017). The effect of organic dust exposure on long-term change in lung function: a systematic review and meta-analysis. Occup Environ Med., 74 531-542.

Brandt M. E., Warnock D. W. (2007). Histoplasma, Blastomyces, Coccidioides, and Other Dimorphic Fungi Causing Systemic Mycoses. In P. R. Murray, E. J. Baron, J. H. Jorgensen, M. L. Landry \& M. A. Pfaller (Eds.), Manual of Clinical Microbiology, 9th ed., pp. 18571873. Washington, D.C.: ASM Press.

Breum N.O., Nielsen B.H., Moller Nielsen E., Poulsen O.M. (1996). Bio-aerosol exposure during collection of mixed domestic waste - An intervention study on compactor truck design. Waste Manag Res, 14, 527-536.
Brown N.J. (2005). Health and Safety Guidance for Composting in the School Setting. ILR Collection. Cornell University ILR School. https://digitalcommons.ilr.cornell.edu/cgi/viewcontent. cgi?referer=https://www.google.fr/\&httpsredir=1\&article $=1008 \& \mathrm{c}$ ontext=manuals (accessed 19 December 2018)

Bunch C. and Crook D.W.M. (1998). Opportunistic infections. In : Encyclopedia of Immunology, I.M. Roitt and P. Delves Eds, Elsevier Inc, Academic Press, Cambridge, MA, USA. ISBN : 0-12-226765-6.

Bünger J., Antlauf-Lammers M., Schulz T.G., Westphal G.A., Müller M.M., Ruhnau P., Hallier E. (2000). Health complaints and immunological markers of exposure to bioaerosols among biowaste collectors and compost workers. Occup. Environ. Med., 57, 458-64.

Bünger J.; Schappler-Scheele B.; Hilgers R.; Hallier E. (2007) A 5-year Follow-up Study on Respiratory Disorders and Lung Function in Workers Exposed to Organic Dust from Composting Plants. Int. Arch. Occup. Environ. Health, 80, 306-312.

Byeon J.H., Park C.W., Yoon K.Y., Park J.H., Hwang J. (2008). Size distributions of total airborne particles and bioaerosols in a municipal composting facility. Bioresour. Technol., 99, 5150-5154.

Carducci A., Federigi I., Verani M. (2013). Virus occupational exposure in solid waste processing facilities. Ann Occup Hyg. ,57, 1115-27.

Cartwright, C., Horrocks, S., Kirton, J., Crook, B. (2009). Review of methods to measure bioaerosols from composting sites. Environment Agency, Science report: SC040021/SR3. https://www. gov.uk/government/uploads/system/uploads/attachment_data/ file/291531/scho0409bpvk-e-e.pdf (accessed 31/08/2018)

Cavallazzi R., Ramirez J.A. (2018). Influenza and Viral Pneumonia. Clin Chest Med., 39, 703-721.

CEN, Comité Européen de Normalisation. (2000). Workplace atmosphere-Guidelines for measurement of airborne micro-organisms and endotoxin. (CEN standard EN 13098). CEN, Brussels, Belgium.

CEN, Comité Européen de Normalisation. (2003). Workplace atmosphere- Determination of airborne endotoxins. (CEN standard EN 14031). CEN, Brussels, Belgium.

CEN, Comité Européen de Normalisation. (2004). Workplace atmospheres. Volumetric bioaerosol sampling devices. Requirements and test methods. (CEN standard EN 14583). CEN, Brussels, Belgium.

Cerna K., Wittlingerová Z., Zimová M., Janovský Z. (2017). Exposure to airborne fungi during sorting of recyclable plastics in waste treatment facilities. Med Pr., 68, 1-9.

Clark N.J., Soares Magalhães R.J. (2018). Airborne geographical dispersal of $\mathrm{Q}$ fever from livestock holdings to human communities: a systematic review and critical appraisal of evidence. BMC Infect Dis., 18, 218.

Clifton, I. J., Peckham, D. G. (2010). Defining routes of airborne transmission of Pseudomonas aeruginosa in people with cystic fibrosis. Expert Review of Respiratory Medicine, 4, 519-529.

Conza L., Pagani S.C., Gaia V. (2013). Presence of Legionella and free-living Amoebae in composts and bioaerosols from composting facilities. PLoS One, 8, e68244.

Cornillet, A., Camus, C., Nimubona, S., Gandemer, V., Tattevin, P., Belleguic, C., et al. (2006). Comparison of epidemiological, clinical, and biological features of invasive aspergillosis in neutropenic and non-neutroopenic patients : a 6-year survey. Clin. Infect. Dis., 43, 577-84.

Currie S.L., Beattie T.K., Knapp C.W., Lindsay D.S. (2014). Legionella spp. in UK composts-a potential public health issue? Clin Microbiol Infect., 20, 0224-9.

Danneberg G., Grüneklee E., Seitz M., Hartung J., Driesel A.J. (1997). Microbial and endotoxin immissions in the neighborhood of a composting plant. Ann. Agric. Environ. Med., 4, 169-173.

Deacon L.J., Pankhurst L.J., Drew G.H., Hayes E.T., Jackson S., Longhurst P.J., Longhurst J.W.S., Liu J., Pollard S.J.T., Tyrrel S.F. (2009a). Particle size distribution of airborne Aspergillus fumigatus spores emitted from compost using membrane filtration. Atmos. Environ., 43, 5698-5701.

Deacon L., Pankhurst L., Liu J., Drew G.H., Hayes E.T., Jackson S., Longhurst J., Longhurst P., Pollard S., Tyrrel S. (2009b). Endotoxin emissions from commercial composting activities. Environ Health, 8 Suppl 1, S9.

Degois J., Clerc F., Simon X., Bontemps C., Leblond P., Duquenne P. (2017). First metagenomic survey of the microbial diversity in bioaerosols emitted in waste sorting plants. Ann. Work Expo. Health, 61, 1076-1086. 
Denning D.W., Pleuvry A., Cole D.C. (2013). Global burden of allergic bronchopulmonary aspergillosis with asthma and its complication chronic pulmonary aspergillosis in adults. Med. Mycol., 51, 361-70.

Denning D.W., Pashley C., Hartl D., Wardlaw A., Godet C., Del Giacco S., Delhaes L., Sergejeva S. (2014). Fungal allergy in asthma - State of the art and research needs. Clin. Transl. Allergy, 4, 14.

Donnelly P.J., Stewart R.K., Ali S.L., Conlan A.A., Reid K.R., Petsikas D., Massey T.E. (1996). Biotransformation of aflatoxin B1 in human lung. Carcinogenesis, 17, 2487-94.

Douglas P., Bakolis I., Fecht D., Pearson C., Leal Sanchez M., Kinnersley R., de Hoogh K., Hansell A.L. (2016). Respiratory hospital admission risk near large composting facilities. Int. J. Hyg. Environ. Health, 219, 372-9.

Douglas P., Hayes E.T., Williams W.B., Tyrrel S.F., Kinnersley R.P., Walsh K., O'Driscoll M., Longhurst P.J., Pollard S.J.T., Drew G.H. (2017). Use of dispersion modelling for Environmental Impact Assessment of biological air pollution from composting: Progress, problems and prospects. Waste Manag., 70, 22-29.

Douwes J.; Wouters I.; Dubbeld H.; Van Zwieten L.; Steerenberg P.; Doekes G.; Heederik D. (2000) Upper Airway Inflammation Assessed by Nasal Lavage in Compost Workers: A Relation with Bioaerosol Exposure. Am. J. Ind. Med., 37, 459-68.

Douwes J., Mannetje A., Heederik D. (2001). Work-related symptoms in sewage treatment workers. Ann Agric Environ Med., 8, 39-45.

Douwes J., Thorne P., Pearce N., Heederik D. (2003). Bioaerosol health effects and exposure assessment: Progress and prospects. Ann. Occup. Hyg., 47, 187-200.

Drummond W.K., Kasperbauer S.H. (2019). Nontuberculous Mycobacteria: Epidemiology and the Impact on Pulmonary and Cardiac Disease. Thorac. Surg. Clin. 29, 59-64.

Dubuis M.E., M'Bareche H., Veillette M., Bakhiyi B., Zayed J., Lavoie J., Duchaine C. (2017). Bioaerosols concentrations in working areas in biomethanization facilities. J. Air Waste Manag. Assoc., 67 1258-1271.

Duquenne P., Marchand G., Duchaine C. (2013). Measurement of endotoxins in bioaerosols at workplace: a critical review of literature and a standardization issue. Ann. Occup. Hyg., 57, 137-72.

Duquenne P. (2018). On the identification of culturable microorganisms for the assessment of biodiversity in bioaerosols. Ann. Work Expo. Health, 62, 139-146.

Dutkiewicz J. (1997). Bacteria and fungi in organic dust as potential health hazard. Ann. Agric. Environ. Med., 4, 11-16.

Eames I., Tang J.W., Li Y., Wilson P. (2009). Airborne transmission of disease in hospitals. J. R. Soc. Interface., 6, Suppl 6, S697-702.

Eduard W., Heederik D. (1998). Methods for quantitative assessment of airborne levels of non-infectious microorganisms in highly contaminated work environments. Am. Ind. Hyg. Assoc. J., 59, 113-127.

Eduard W., Douwes J., Omenaas E., Heederik D. (2004). Do farming exposures cause or prevent asthma? Results from a study of adult Norwegian farmers. Thorax, 59, 381-6.

Eduard W. (2009). Fungal spores: a critical review of the toxicological and epidemiological evidence as a basis for occupational exposure limit setting. Crit. Rev. Toxicol., 39, 799-864.

Eduard W., Heederik D., Duchaine C., Green B.J. (2012). Bioaerosol exposure assessment in the workplace: the past, present and recent advances. J. Environ. Monit., 14, 334-339.

Environment Agency (2018). Technical Guidance Note (Monitoring) M9 : Environmental monitoring of bioaerosols at regulated facilities, version 2. https://www.gov.uk/government/publications/m9environmental-monitoring-of-bioaerosols-at-regulated-facilities (accessed 31/08/2018)

Epstein E. (1994). Composting and Bioaerosols. Biocycle, 35, 51-58.

Epstein E. (1996). Protecting workers at composting facilities. Biocycle, 37, 69-77.

Epstein E.; Wu N.; Youngberg C.; Croteau G. (2001) Controlling Dust and Bioaerosols at a Biosolids Composting Facility. Biocycle, 41, 50-54.

Fairs A., Agbetile J., Hargadon B., Bourne M., Monteiro W.R., Brightling C.E., Bradding P., Green R.H., Mutalithas K., Desai D., Pavord I.D. Wardlaw A.J., Pashley C.H. (2010). IgE sensitization to Aspergillus fumigatus is associated with reduced lung function in asthma. Am. J. Respir. Crit. Care Med., 182, 1362-8

Felten C., Küppers M., Missel T., (2001). Measures to assess and to reduce microbiological pollution in waste sorting plants. In: Proceedings of the International Social Security Association Chemistry Section and ISSA Research Section International Symposium, pp. 174-178, Dusts, fumes and mists in the workplace: risks and their prevention, Toulouse, France, 11-13 June 2001.
Fischer J.L., Beffa T., Lyon P-F., Aragno M. (1998). Aspergillus fumigatus in windrow composting: effect of turning frequency. Waste Manag. Res., 16, 320-29.

Galès, A., Bru-Adan, V., Godon, J.-J., Delabre, K., Catala, P., Ponthieux A., Chevallier, M., Birot, E., Steyer, J.-P., Wéry, N. (2015). Predominance of single bacterial cells in composting bioaerosols. Atmos. Environ. 107, 225-232.

Garden Organic (accessed 2018). Making Compost in Schools. https://digitalcommons.ilr.cornell.edu/cgi/viewcontent. cgi?referer=https://www.google.fr/\&httpsredir=1\&article $=1008 \& c$ ontext=manuals. Accessed 19 December 2018.

Gladding, T.L., Coggins, P.C. (1997). Exposure to microorganisms and health effects of working in UK materials recovery facilities - a preliminary report. Ann. Agric. Environ. Med., 4, 137-141.

Gladding T., Thorn J., Stott D. (2003). Organic dust exposure and work-related effects among recycling workers. Am. J. Indus. Med., 43, 584-591

Gladding T.L., Gwyther C.L. (2017). A study of the potential release of bioaerosols from containers as a result of reduced frequency residual waste collections. Sci. Total Environ., 576, 481-489.

Gerba C.P., Huber M.S., Naranjo J., Rose J.B., Bradford S (1995). Occurrence of enteric pathogens in composted domestic solid waste containing disposable diapers. Waste Manag. Res., 13, 315-314.

Gerba C.P., Tamimi A.H., Pettigrew C., Weisbrod A.V., Rajagopalan V. (2011). Sources of microbial pathogens in municipal solid waste landfills in the United States of America. Waste Manag Res., 29, 781-90.

Green Mountain Farm to School (2010). A guide to starting composting program in your school. http://greenmountainfarmtoschool.org/ wp-content/uploads/2016/01/Guide-to-Staring-a-School-Compost-Program.pdf (accessed 19 December 2018).

Hambach R., Droste J., François G., Weyler J., Van Soom U., De Schryver A., Vanoeteren J., van Sprundel M. (2012). Work-related health symptoms among compost facility workers: a cross-sectional study. Arch. Public Health, 70, 13-18.

Health Council of the Netherlands (2010). Endotoxins - Health-based recommended occupational exposure limit. The Hague: Health Council of the Netherlands, publication no. 2010/040SH. https:// www.healthcouncil.nl/documents/advisory-reports/2010/07/15/ endotoxins-health-based-recommended-occupational-exposurelimit (accessed 08/10/2018)

Heldal K. K.; Halstensen A. S.; Thorn J.; Eduard W.; Halstensen T. S. (2003). Airway Inflammation in Waste Handlers Exposed to Bioaerosols Assessed by Induced Sputum. Eur. Respir. J., 21, 641-45.

Heldal K.K., Eduard W. (2004). Associations between acute symptoms and bioaerosols exposure during the collection of household waste. Am. J. Ind. Med., 46, 253-60.

Heldal K.K., Mads $\varnothing$ L., Eduard W. (2015). Airway inflammation among compost workers exposed to actinomycetes spores. Ann. Agric. Environ. Med., 22, 253-8.

Herr C.E., zur Nieden A., Jankofsky M., Stilianakis N.I., Boedeker R.H., Eikmann T.F. (2003). Effects of bioaerosol polluted outdoor air on airways of residents: a cross sectional study. Occup Environ Med. $60,336-42$

Herr C.E., zur Nieden A., Stilianakis N.I., Gieler U., Eikmann T.F. (2004) Health effects associated with indoor storage of organic waste. Int. Arch. Occup. Environ. Health, 77, 90-6.

Herwaldt L.A., Marra A.R. (2018). Legionella: a reemerging pathogen Curr. Opin. Infect. Dis., 31, 325-333.

Hoffmeyer F., van Kampen V., Taeger D., Deckert A., Rosenkranz N., Kaßen M., Schantora A.L., Brüning T., Raulf M., Bünger J. (2014). Prevalence of and relationship between rhinoconjunctivitis and lower airway diseases in compost workers with current or former exposure to organic dust. Ann. Agric. Environ. Med., 21, 705-11.

Hogerwerf L., De Gier B., Baan B., van der Hoek W. (2017). Chlamydia psittaci (psittacosis) as a cause of community-acquired pneumonia: a systematic review and meta-analysis. Epidemiol Infect., 145 3096-3105.

Holla A.D., Roy S.R., Liu A.H. (2002). Endotoxin, atopy and asthma. Curr Opin Allergy Clin Immunol., 2, 141-145

Huang, C.H., Lee, C.C., Li, F.C., Ma, Y.P., Su, H.J.J. (2002). The seasonal distribution of bioaerosols in municipal landfill sites : a 3-yr study. Atmos. Environ., 36, 4385-95

IARC (2012). Aflatoxins. In : International Agency for Research on Cancer, Monograph 100 F, pp. 225-248. ISBN 9789283213239

https://monographs.iarc.fr/wp-content/uploads/2018/06/mono100F-23.pdf (accessed 08/10/2018). 
Ibanga I.E., Fletcher L.A., Noakes C.J., King M.F., Steinberg D. (2018). Pilot-scale biofiltration at a materials recovery facility: The impact on bioaerosol control. Waste Manag., 80, 154-167.

INRS (2011). Centres de tri de déchets recyclables secs ménagers et assimilés issus des collectes séparées. In: INRS (Ed.) Guide de prévention pour la conception, ED 6098, Paris, p. 59. http:// www.inrs.fr/accueil/produits/mediatheque/doc/publications. html?refINRS=ED\%206098.

Ivens U.I., Breum N.O., Ebbehøj N., Nielsen B.H., Poulsen O.M., Würtz $H$. (1999). Exposure-response relationship between gastrointestinal problems among waste collectors and bioaerosol exposure. Scand. J. Work Environ. Health, 25, 238-45.

Jakšić D., Puel O., Canlet C., Kopjar N., Kosalec I., Klarić M.Š. (2012). Cytotoxicity and genotoxicity of versicolorins and 5-methoxysterigmatocystin in A549 cells. Arch Toxicol., 86, 1583-91.

Jung N., Mronga S., Schroth S., Vassiliou T., Sommer F., Walthers E., Aepinus C., Jerrentrup A., Vogelmeier C., Holland A., Koczulla R. (2014). Gardening can induce pulmonary failure: Aspergillus ARDS in an immunocompetent patient, a case report. BMC Infect. Dis., 14, 600.

Kalwasinska A., Burkowska A., Swiontek-Brzezinska M. (2014). Exposure of workers of municipal landfill site to bacterial and fungal aerosol. Clean-Soil, Air, Water, 42, 1337-43.

Knutsen A.P., Slavin R.G. (2011). Allergic bronchopulmonary aspergillosis in asthma and cystic fibrosis. Clin. Dev. Immunol., 843763.

Krajewski J.A., Tarkowski S., Cyprowski M., Szarapińska-Kwaszewska J., Dudkiewicz B. (2002). Occupational exposure to organic dust associated with municipal waste collection and management. Int. J. Occup. Med. Environ. Health.,15, 289-301.

Krajewski J.A., Cyprowski M., Szymczak W., Gruchala J. (2004). Health complaints from workplace exposure to bioaerosols: a questionnaire study in sewage workers. Ann. Agric. Environ. Med., 11, 199204.

Kramer M. N., Kurup V. P., Fink, J. N.(1989). Allergic Bronchopulmonary Aspergillosis from a Contaminated Dump Site. Am. Rev. Respir. Dis., 140, 1086-88.

Lande L., George J., Plush T. (2018). Mycobacterium avium complex pulmonary disease: new epidemiology and management concepts. Curr Opin Infect Dis., 31, 199-207.

Latgé, J-P. (1999). Aspergillus fumigatus and aspergillosis. Clin. Microbiol. Rev., 12, 310-50.

Lavoie J., Dunkerley C.J. (2002). Assessing waste collectors' exposure to bioaerosols. Aerobiologia, 18, 3-4, 227-285.

Le Goff O., Bru-Adan V., Bacheley H., Godon J.J., Wery N. (2010). The microbial signature of aerosols produced during the thermophilic phase of composting. J. Appl. Microbiol., 108, 325-340.

Le Goff, O., Godon, J-J., Milferstedt, K., Bacheley, H., Steyer, J-P., Wéry N. (2012). A new combination of microbial indicators for monitoring composting bioaerosols. Atmos. Environ., 61, 428-433.

Lemonovich T.L. (2018). Mold Infections in Solid Organ Transplant Recipients. Infect. Dis. Clin. North Am., 32, 687-701.

Lenters V., Basinas I., Beane-Freeman L., Boffetta P., Checkoway H., Coggon D., Portengen L., Sim M., Wouters I.M., Heederik D., Vermeulen R. (2010). Endotoxin exposure and lung cancer risk: a systematic review and meta-analysis of the published literature on agriculture and cotton textile workers. Cancer Causes Control, 21, 523-55.

Letsrecycle.com (2009). Time bomb warning over impact of bioaerosols on workers. News, Organics, 16 July 2009.

https://www.letsrecycle.com/news/latest-news/time-bomb-warningover-impact-of-bioaerosols-on-workers/

Liebers V., Raulf-Heimsoth M., Brüning T. (2008). Health effects due to endotoxin inhalation (review). Arch Toxicol., 82, 203-10.

Lin X. (2009). Cryptococcus neoformans: Morphogenesis, infection, and evolution. Infection, Genetics and Evolution, 9, 401-416.

Lis D., Ulfig K., Wlazlo A., Pastuska J.S. (2004). Microbial air quality in offices at municipal landfills. J. Occup. Environ. Hyg. 1, 62-68.

Ma L., Cissé O.H., Kovacs J.A. (2018). A Molecular Window into the Biology and Epidemiology of Pneumocystis spp. Clin. Microbiol. Rev., 31, 3.

Madsen A.M., Alwan T., Ørberg A., Uhrbrand K., Jørgensen M.B. (2016). Waste Workers Exposure to Airborne Fungal and Bacterial Species in the Truck Cab and During Waste Collection. Ann. Occup. Hyg., $60,651-68$

Maloney S.A., Pearson M.L., Gordon M.T., Del Castillo R., Boyle J.F., Jarvis W.R. (1995). Efficacy of control measures in preventing nosocomial transmission of multidrug-resistant tuberculosis to patients and health care workers. Ann. Intern. Med., 122, 90-5.
Marchese S., Polo A., Ariano A., Velotto S., Costantini S., Severino L. (2018). Aflatoxin B1 and M1: Biological Properties and Their Involvement in Cancer Development. Toxins (Basel), 10, 6 .

Massey T.E., Smith G.B., Tam A.S. (2000). Mechanisms of aflatoxin B1 lung tumorigenesis. Exp Lung Res., 26, 673-83.

Mbareche H., Veillette M., Bonifait L., Dubuis M.E., Benard Y., Marchand G., Bilodeau G.J., Duchaine C. (2017). A next generation sequencing approach with a suitable bioinformatics workflow to study fungal diversity in bioaerosols released from two different types of composting plants. Sci. Total Environ., 601-602, 1306-1314.

Mbareche H., Veillette M., Dubuis M.Ė., Bakhiyi B., Marchand G., Zayed J., Lavoie J., Bilodeau G.J., Duchaine C. (2018). Fungal bioaerosols in biomethanization facilities. J. Air Waste Manag. Assoc., 68, 1198-1210.

McKinsey D.S., McKinsey J.P. (2011). Pulmonary histoplasmosis. Semin. Respir. Crit. Care Med., 32, 735-44.

Michel O., Duchateau J., Sergysels R. (1989). Effect of inhaled endotoxin on bronchial reactivity in asthmatic and normal subjects. J. Appl. Physiol., 66, 1059-64.

Miller P.A., Clesceri N.L. (2002). Waste Sites as Biological Reactors: Characterization and Modelling. CRC Press, Boca Raton. eBook ISBN 9781420032499.

Millner P. D., Olenchock S. A., Epstein E., Rylander R., Haines J., Walker J., Ooi B. L., Home E., Maritato M. (1994) Bioaerosols Associated with Composting Facilities. Compost Sci. Util., 2, 6-57.

Moretti M.L., Busso-Lopes A.F., Tararam C.A., Moraes R., Muraosa Y., Mikami Y., Gonoi T., Taguchi H., Lyra L., Reichert-Lima F., Trabasso P., de Hoog G.S., Al-Hatmi A.M.S., Schreiber A.Z., Kamei K. (2018). Airborne transmission of invasive fusariosis in patients with hematologic malignancies. PLoS One, 13, e0196426.

Morey P.R., Hoffman B.H. (2003). Enclosure of composting operations to minimize bioaerosols emissions into ambient air. Appl. Biosafety, 8, 62-67.

Naegele A., Reboux G., Vacheyrou M., Valot B., Millon L., Roussel S. (2016). Microbiological consequences of indoor composting. Indoor Air, 26, 605-613.

Nasir Z.A., Rolph C., Collins S., Stevenson D., Gladding T.L., Hayes E., Williams B., Khera S., Jackson S., Bennett A., Parks S., Kinnersley R.P., Walsh K., Pollard S.J.T., Drew G., Garcia Alcega S., Freeric CouIon F., Tyrrel S. (2018a). A Controlled Study on the Characterisation of Bioaerosols Emissions from Compost. Atmosphere, 9, 379-94.

Nasir Z.A., Hayes E., Williams B., Gladding T., Rolph C., Khera S., Jack son S., Bennett A., Collins S., Parks S., Attwood A., Kinnersley .R.P, Walsh K., Alcega S.G., Pollard S.J.T., Drew G., Coulon F., Tyrrel S. (2018b). Scoping studies to establish the capability and utility of a real-time bioaerosol sensor to characterise emissions from environmental sources. Sci. Total Environ., 648, 25-32.

National Health Service (2008). Fungal exposure and gardening. 13 June 2008 https://www.nhs.uk/news/lifestyle-and-exercise/fungal-exposure-and-gardening/ (accessed 19 December 2018).

Neumann H.D., Balfanz J., Becker G., Lohmeyer M., Mathys W., Raulf-Heimsoth M. (2002). Bioaerosol exposure during refuse collection: results of field studies in the real-life situation. Sci. Total Environ. ,293, (1-3), 219-231.

Neumann H.D., Becker G., Lohmeyer M., Mathys W. (2005). Preventive measures to reduce bioaerosol exposure during refuse collection: results of field studies in the real-life situation. Sci. Total Environ., 341, (1-3), 1-13.

Nielsen E.M., Nielsen B.H., Breum N.O. (1995). Occupational bioaerosol exposure during collection of household waste. Ann. Agric. Environ Med., 2, 53-59.

O'Connor D.J., Daly S.M., Sodeau J.R. (2015). On-line monitoring of airborne bioaerosols released from a composting/green waste site. Waste Manag., 42, 23-30.

Oppliger A., Duquenne P. (2015). Highly contaminated workplaces. In : Environmental Mycology in Public Health; Carla Viegas, Ana Catarina Pinheiro, Raquel Sabino, Susana Viegas, João Brandão and Cristina Veríssimo eds., Elsevier Inc., Academic Press, Cambridge, MA, USA. ISBN: 978-0-12-411471-5

Pahren H.R. (1987). Microorganisms in municipal solid waste and public health implications. CRC Crit. Rev. Environ. Control. 17, 187-228.

Palmisano A.C., Barlaz M.A. (1996). Microbiology of solid waste. CRC Press, Boca Raton. ISBN 9780849383618.

Pankhurst L.J., Akeel U., Hewson C., Maduka I., Pham P., Saragossi J. Taylor J., Lai K.M. (2011a). Understanding and mitigating the challenge of bioaerosol emissions from urban community composting. Atmos. Environ., 45, 85-93. 
Pankhurst L.J., Deacon L.J., Liu J., Drew G.H., Hayes E.T., Jackson S., Longhurst P.J., Longhurst J.W., Pollard S.J., Tyrrel S.F. (2011b). Spatial variations in airborne microorganism and endotoxin concentrations at green waste composting facilities. Int. J. Hyg. Environ. Health, 214, 376-83.

Pankhurst L.J., Whitby C., Pawlett M., Larcombe L.D., McKew B., Deacon L.J., Morgan S.L., Villa R., Drew G.H., Tyrrel S., Pollard S.J., Coulon F. (2012). Temporal and spatial changes in the microbial bioaerosol communities in green-waste composting. FEMS Microbiol. Ecol., 79, 229-39.

Park D-U., Ryu S-H., Kim S-B., Yoon C-S. (2011a). An assessment of dust, endotoxin, and microorganism exposure during waste collection and sorting. J. Air \& Waste Manage. Assoc. 61, 461-468.

Park C.W., Byeon J.H., Yoon K.Y., Park J.H., Hwang J. (2011b). Simultaneous removal of odors, airborne particles, and bioaerosols in a municipal composting facility by dielectric discharge. Sep. Purif. Technol., 77, 87-93.

Pearson C., Littlewood E., Douglas P., Robertson S., Gant T.W., Hansell A.L. (2015). Exposures and health outcomes in relation to bioaerosol emissions from composting facilities: a systematic review of occupational and community studies. J. Toxicol. Environ. Health B Crit. Rev., 18, 43-69.

Persoons R., Parat S., Stoklov M., Perdrix A., Maitre A. (2010). Critical working tasks and determinants of exposure to bioaerosols and MVOC at composting facilities. Int. J. Hyg. Environ. Health, 213,338-47.

Pinto M.J., Veiga J.M., Fernandes P., Ramos C., Gonçalves S., Velho M.M., Guerreiro J.S. (2015). Airborne microorganisms associated with packaging glass sorting facilities. J. Toxicol. Environ. Health A. $78,685-96$

Qian H., Zheng X. (2018). Ventilation control for airborne transmission of human exhaled bio-aerosols in buildings. J. Thorac. Dis., 10, S2295-S2304.

Quirce S., Vandenplas O., Campo P., Cruz M.J., de Blay F., Koschel D., Moscato G., Pala G., Raulf M., Sastre J., Siracusa A., Tarlo S.M., Walusiak-Skorupa J., Cormier Y. (2016). Occupational hypersensitivity pneumonitis: an EAACI position paper. Allergy, 71, 765-79.

Rahkonen P., Ettala M., Laukkanen M., Salkinoja-Salonen, M. (1990). Airborne microbes and endotoxins in the work environment of two sanitary landfills in Finland. Aerosol Sci. Technol. 13, 505-513.

Rapp R., Fontaine J.-R., Henry F., Duquenne P., Koehler V., Greff G., Liang S., Görner P., Becker A. (2009). Air diffusion in sorting rooms at domestic waste treatment centres. What work station ventilation? Hygiène et Sécurité du Travail, 2, 215-230 (article in French).

Ray M.R., Roychoudhury S., Mukherjee G., Roy S., Lahiri T. (2005). Respiratory and general health impairments of workers employed in a municipal solid waste disposal at an open landfill site in Delhi. Int. J. Hyg. Environ. Health, 208, 255-62.

Raynor G.S., Hayes J.V., Ogden E.C. (1974). Particulate dispersion into and within a forest. Boundary-Layer Meteorol., 7, 429-56

Recer, G.M., Browne, M.L., Horn, E.G., Hill, K.M., Boehler, W.F. (2001). Ambient air levels of Aspergillus fumigatus and thermophilic actinomycetes in a residential neighborhood near a yard-waste composting facility. Aerobiologia, 17, 99-108.

Reinthaler, F.F., Haas, D., Feierl, G., Schlacher, R., Pichler-Semmelrock, F.P., Föck, M., Wüst, G., Feenstra, O., Marth, E. (1999). Comparative investigations of airborne culturable microorganisms in selected waste treatment facilities and in neighbouring residential areas. Zbl. Hyg. Umwleltmed., 202, 1-17.

Reinthaler F.F., Wüst G., Haas D., Feierl G., Ruckenbauer G., Marth E. (2004). Simple emission-reducing measures in an open biological waste treatment plant. Aerobiologia, 20, 83-88.

Riedler J., Braun-Fahrländer C., Eder W., Schreuer M., Waser M., Maisch S., Carr D., Schierl R., Nowak D., von Mutius E.; ALEX Study Team (2001). Exposure to farming in early life and development of asthma and allergy: a cross-sectional survey. Lancet, 358, 1129-33.

Robinson, N.H., Allan, J.D., Huffman, J.A., Kaye, P.H., Foot, V.E., Gallagher, M. (2013). Cluster analysis of WIBS single-particle bioaerosol data. Atmos. Meas. Tech., 6, 337-347.

Roden M. M., Zaoutis T. E., Buchanan W. L., Knuclsen T. A., Sarkisova T. A., Schaufele R. L., Sein M., Sein T., Chiou C. C., Chu J. H. (2005). Epidemiology and outcome of zygomycosis: A review of 929 reported cases. Clin. Infect. Dis., 41, 634-653.

Rolph, C., Gladding, T.L. (2017). Size fractionation of endotoxin from organic waste. Proceedings Sardinia 2017, Sixteenth International Waste Management and Landfill Symposium, 2-6 October 2017, S. Margherita di Pula, Cagliari, Italy.
Russell K., Broadbridge C., Murray S., Waghorn D., Mahoney A. (2008). Gardening can seriously damage your health. Lancet, 371, 2056.

Rylander R. (2006). Endotoxin and occupational airway disease. Curr Opin Allergy Clin Immunol., 6,62-6.

Rylander R., Jacobs R.R. (1994). Organic Dusts. Exposure, Effects and Prevention. Boca Raton: Lewis Publishers, CRC Press 320 p.. ISBN 9780873716994

Sanchez-Monedero M.A., Stentiford E.I., Mondini C. (2003). Biofiltration at composting facilities: effectiveness for bioaerosol control. Environ. Sci. Technol., 37, 4299-303.

Sanchez-Monedero M.A., Stentiford E.I., Urpilainen S.T. (2005). Bioaerosol generation at large-scale green waste composting plants. J. Air Waste Manag. Assoc., 55, 612-8.

Schantora A.L., Casjens S., Deckert A., van Kampen V., Neumann H.D., Brüning T., Raulf M., Bünger J., Hoffmeyer F. (2015). Prevalence of work-related rhino-conjunctivitis and respiratory symptoms among domestic waste collectors. Adv. Exp. Med. Biol., 834:53-61.

Schlegelmilch M., Herold T., Streese J., Hensel A., Stegmann R. (2005). The potential to reduce emissions of airborne microorganisms by means of biological waste gas treatment systems. Waste Manag. $25,955-64$

Schlosser O., Huyard A., Cartnick K., Yanez A., Catalan V., Do Quang Z. (2009). Bioaerosol in composting facilities : Occupational health risk assessment. Water Environ. Res., 81, 866-877.

Schlosser O., Huyard A., Rybacki D., Do Quang Z. (2012). Protection of the vehicle cab environment against bacteria, fungi and endotoxins in composting facilities. Waste Manag., 32, 1106-15.

Schlosser O., Déportes I.Z., Facon B., Fromont E. (2015). Extension of the sorting instructions for household plastic packaging and changes in exposure to bioaerosols at materials recovery facilities. Waste Manag., 46, 47-55.

Schlosser O., Robert S., Debeaupuis C. (2016). Aspergillus fumigatus and mesophilic moulds in air in the surrounding environment downwind of non-hazardous waste landfill sites. Int. J. Hyg. Environ. Health, 219, 239-51.

Schlosser O., Robert S., Peron M., Debeaupuis C. (2017). Appraising a "safe" buffer distance around waste disposal facilities - a case study of moulds and Aspergillus fumigatus in air in the surrounding environment of non-hazardous waste landfill sites. Proceedings Sardinia 2017 / Sixteenth International Waste Management and Landfill Symposium/ 2 - 6 October 2017. S. Margherita di Pula, Cagliari, Italy. https://cisapublisher.com/product/sardinia2017-proceedings-usb-card/ (accessed 08/10/2018)

Schlosser O., Robert S., Debeaupuis C., Huyard A. (2018). Inhalable dust as a marker of exposure to airborne biological agents in composting facilities. Waste Manag., 81, 78-87.

Schuijs M.J., Willart M.A., Vergote K., Gras D., Deswarte K., Ege M.J., Madeira F.B., Beyaert R., van Loo G., Bracher F., von Mutius E., Chanez P., Lambrecht B.N., Hammad H. (2015). Farm dust and endotoxin protect against allergy through A20 induction in lung epithelial cells. Science, 349, 1106-10.

Searl A. (2008). Exposure-response relationships for bioaerosol emissions from waste treatment processes. IOM Report for DEFRA, WR 0606, 208 p. http://sciencesearch.defra.gov.uk/Default.aspx?Me nu=Menu\&Module=More\&Location=None\&Completed=0\&Project ID=15140 (accessed 08/10/2018)

Sigsgaard T., Abel A., Donbaek L., Malmros P. (1994). Lung function changes among recycling workers exposed to organic dust. Am. J. Indus. Med., 25, 69-72.

Spaan S., Schinkel J., Wouters I.M., Preller L., Tielemans E., Nij E.T. Heederik D. (2008). Variability in endotoxin exposure levels and consequences for exposure assessment. Ann. Occup. Hyg., 52, 303-316.

Spencer R.; Alix C. M. (2006). Dust Management, Mitigation at Composting Facilities. Biocycle, 47, 55-57.

Stagg S., Vince Sandys LFOH, Crook B., Wood J., McAlinden J. (2013). Occupational Hygiene implications of processing waste at Materials Recycling Facilities (MRFs)-Exposure to bioaerosol and dust. Health and Safety Laboratory, Buxton. Health and Safety Executive research report RR977. http://www.hse.gov.uk/research/rrpdf/ rr977.pdf (accessed 19/12/2018)

Swan J.R.M., Kelsey A., Crook B., Gilbert E.J. (2003). Occupational and environmental exposure to bioaerosols from composts and potential health effects - A critical review of published data. Health Safety Executive, UK, Research report 130. 
Sykes P., Jones K., Wildsmith J.D. (2007). Managing the potential public health risks from bioaerosol liberation at commercial composting sites in the UK: An analysis of the evidence base. Resour. Cons. Recyc., 52, 410-424.

Sykes P., Morris R.H., Allen J.A., Wildsmith J.D., Jones K.P. (2011). Workers' exposure to dust, endotoxin and $\beta-(1-3)$ glucan at four large-scale composting facilities. Waste Manag., 31, 423-30.

Taha M.P.M., Drew G.H., Longhurst P.J., Smith R., Pollard S.J.T. (2006). Bioaerosol releases from compost facilities: Evaluating passive and active source terms at a green waste facility for improved risk assessments. Atmos. Environ., 40, 1159-1169.

Tolvanen O.K. (2001). Airborne bio-aerosols and noise in a dry waste treatment plant in Pietarsaari. Finland Waste Manage. Res., 19, $108-114$.

Tolvanen O.K. (2004). Exposure to bioaerosols and noise at a Finnish dry waste treatment plant. Waste Manage. Res., 22, 346-357.

Tolvanen O.K., Hänninen K.I. (2006). Mechanical-biological waste treatment and the associated occupational hygiene in Finland. Waste Manag., 26, 1119-25.

Traversi D., Gorrasi I., Pignata C., Degan R., Anedda E., Carletto G., Vercellino G., Fornasero S., Bertino A., Filippi F., Gullo M., Gilli G. (2018). Aerosol exposure and risk assessment for green jobs involved in biomethanization. Environ Int., 114, 202-211.

Tschopp A., Bernard A., Thommen A.M., Jeggli S., Dumont X., Oppliger A., Hotz P. (2011). Exposure to bioaerosols, respiratory health and lung-specific proteins: a prospective study in garbage and wastewater workers. Occup. Environ. Med., 2011, 68, 856-9.

USEPA, United States Environmental Protection Agency. Human health risk assessment. epa.gov/risk/human-health-risk-assessment (accessed 14 December 2018)

Valade S., Azoulay E., Damiani C., Derouin .F, Totet A., Menotti J. (2015). Pneumocystis jirovecii airborne transmission between critically ill patients and health care workers. Intensive Care Med., 41, 1716-8.

van Kampen V., Sander I., Liebers V., Deckert A., Neumann H.D., Buxtrup M., Willer E., Felten C., Jäckel U., Klug K., Brüning T., Raulf M., Bünger J. (2014). Concentration of bioaerosols in composting plants using different quantification methods. Ann. Occup. Hyg., 58, 693-706.

van Kampen V., Hoffmeyer F., Deckert A., Kendzia B., Casjens S., Neumann H.D., Buxtrup M., Willer E., Felten C., Schöneich R., Brüning T., Raulf M., Bünger J. (2016). Effects of bioaerosol exposure on respiratory health in compost workers: a 13-year follow-up study. Occup. Environ. Med., 73, 829-837.

Viegas C., Gomes A.Q., Abegão J., Sabino R., Graça T., Viegas S. (2014). Assessment of fungal contamination in waste sorting and incineration-case study in Portugal. J. Toxicol. Environ. Health A., 77, 57-68.
Viegas S., Caetano L.A., Korkalainen M., Faria T., Pacífico C., Carolino E., Quintal Gomes A., Viegas C. (2017). Cytotoxic and Inflammatory Potential of Air Samples from Occupational Settings with Exposure to Organic Dust. Toxics, 5(1).

Vilavert L., Nadal M., Figueras M.J., Domingo J.L. (2012). Volatile organic compounds and bioaerosols in the vicinity of a municipal waste organic fraction treatment plant. Human health risks. Environ. Sci. Pollut. Res. Int., 19, 96-104.

Walser S.M., Gerstner D.G; Brenner B., Bünger J., Eikman T., Janssen B., Kolb S., Kolk A., Nowak D., Raulf M., Sagunski H., Sedlmaier N., Suchenwirth R., Wiesmüller G., Wollin K-M., Tesseraux I., Herr C.E.W. (2015). Evaluation of exposure-response relationships for health effects of microbial bioaerosols - a systematic review. Int. J. Hyg. Environ. Health, 218, 577-589.

Wéry N. (2014). Bioaerosols from composting facilities - A review. Front. Cell. Infect. Microbiol., 4, 1-9.

Wéry N., Galès A., Brunet Y. (2018). Bioaerosols sources. In Microbiology of aerosols. Delort A.M. and Amato P. ed., John Wiley \& Sons, 320 p. ISBN: 978-1-119-13228-8.

Wouters I. (1999) Endotoxin and ß-(1,3)-glucan Exposure in Household Waste Collectors and Compost Workers: A Relation with Upper Airway Inflammation. Schriftenr. Ve. Wasser Boden. Lufthyg., 104, 546-50.

Wouters I.M., Douwes J., Doekes G., Thorne P.S., Brunekreef B., Heederik D.J. (2000). Increased levels of markers of microbial exposure in homes with indoor storage of organic household waste. Appl. Environ. Microbiol., 66, 627-31.

Wouters I.M., Spaan S., Douwes J., Doekes G., Heederik D. (2006). Overview of personal occupational exposure levels to inhalable dust, endotoxin, $B-(1,3)$-glucan and fungal extracellular polysaccharides in the waste management chain. Ann. Occup. Hyg., 50,39-53.

Würtz H., Breum N.O. (1997). Exposure to microorganisms during manual sorting of recyclable paper of different quality. Ann. Agric. Environ. Med., 4, 129-135.

Yates T.A., Khan P.Y., Knight G.M., Taylor J.G., McHugh T.D., Lipman M., White R.G., Cohen T., Cobelens F.G., Wood R., Moore D.A., Abubakar I. (2016). The transmission of Mycobacterium tuberculosis in high burden settings. Lancet Infect. Dis., 16, 227-38.

Zuk J.A., King D., Zakhour H.D., Delaney J.C. (1989). Locally invasive pulmonary aspergillosis occurring in a gardener: an occupational hazard? Thorax, 44, 678-9. 